\title{
Pengaruh Pengungkapan Tanggung Jawab Sosial Perusahaan, Kepemilikan Keluarga, dan Tata Kelola Perusahaan Terhadap Penghindaran Pajak
}

\author{
Robby Krisyadi ${ }^{1}$, Anita ${ }^{2 *}$ \\ Universitas Internasional Batam ${ }^{1,2}$ \\ Robby.Krisyadi@uib.ac.id, 1842092.anita@uib.edu
}

*Corresponding Author

Diajukan : 19 Desember 2021

Disetujui : 30 Desember 2021

Dipublikasi : 1 Januari 2022

\begin{abstract}
Taxation is an important thing that can add to state income but reduce corporate income or taxes. Therefore, tax avoidance is carried out by corporate management to maximize their corporate earnings. This study aims to examine the effects of corporate social responsibility disclosure, family ownership, and corporate governance on tax avoidance. the ratio of tax avoidance of corporations in this study was proxied by using the Effective Tax Rate (ETR) by comparing the amount of tax burden with pre-tax profit of corporations. Disclosure of corporate social responsibility is proxied with GRI index with number of indicators 91 disclosure items, family ownership is proxied with total percentage of ownership of a family in one company and corporate governance proxied with GG indicator amounts to 15 items. 136 companies listed on the Indonesian stock exchange of the 2016-2020 period were selected as research samples using the purposive sampling technique. data used in this analysis are panel data processed using SPSS and Eviews. SPSS is used to detect outlier data that will then be regressed using Eviews. Research results show that family ownership and disclosure of corporate social responsibility has a significant and positive effect on tax avoidance whereas corporate governance has no effect on tax avoidance.
\end{abstract}

Keywords: Corporate Governance, Corporate Social Responsibility Disclosure, Family Ownership, Tax Avoidance

\section{PENDAHULUAN}

Pada dasarnya, tujuan dari didirikannya sebuah perusahaan ialah untuk mengumpulkan keuntungan yang sebesar-besarnya bagi para pemiliknya. Pajak merupakan iuran wajib yang sering dianggap sebagai biaya dalam perusahaan, hal ini mendorong pihak manajemen perusahaan mengambil langkah untuk mengurangi biaya perpajakan. Salah satu langkah untuk mengurangi biaya perpajakan tersebut adalah penghindaran pajak (Gaaya, Lakhal, \& Lakhal, 2017). Dewi dan Jati (2014) menjelaskan bahwa kegiatan legal serta diperbolehkan dengan menggunakan celah-celah yang ada di peraturan perpajakan untuk menghindari atau mengurangi beban pembayaran pajak merupakan definisi dari penghindaran pajak. Namun, fakta dan unsur yang dikenakan dalam perpajakan tidak dapat dihindari sehingga penghindaran pajak tidak selalu terjadi.

Meskipun sah secara hukum, penghindaran pajak tetap tidak didukung oleh negara. Alasan penghindaran pajak tidak didukung meskipun sah adalah karena hal tersebut akan mengurangi penghasilan negara yang menyebabkan berkurangnya sumber dana untuk pembangunan negara (Handayani \& Ibrani, 2019). Penghindaran pajak dapat menurunkan citra baik perusahaan dalam masyarakat karena dianggap sebagai aktivitas yang tidak bertanggung jawab.

Terdapat juga landasan teori yang mendasari penghindaran pajak, yaitu agency theory. Agency theory adalah teori yang menerangkan dimana terdapatnya kontrak antar pihak pemberi 
wewenang atau biasa disebut sebagai pihak principal dan pihak penerima wewenang atau agent dengan menyerahkan sebagian kekuasaan atas pengambilan keputusan dalam menjalankan sesuatu yang berhubungan dengan kepentingan pihak pemberi wewenang (principal) (Jensen \& Meckling, 1976). Sesuai penjelasan teori tersebut, pemerintah dianggap sebagai pihak pemberi wewenang dan wajib pajak sebagai penerima wewenang. Pemerintah mendorong warganya untuk memenuhi kewajiban sebagai wajib pajak, sedangkan wajib pajak berusaha mencari cara dalam menghindari pajak secara legal maupun ilegal (Sujendra et al., 2019). Hal tersebut terjadi karena adanya perbedaan kepentingan antar kedua belah pihak tersebut.

Sebuah strategi dalam melakukan penghindaran pajak sekaligus menaikkan citra baik perusahaan dalam masyarakat adalah pengungkapan atas tanggung jawab yang dilakukan perusahaan atau biasa disebut sebagai CSRD (Corporate Social Responsibility Disclosure) atas akibat dampak operasional usahanya terhadap pihak-pihak berkepentingan (Ratmono \& Sagala, 2016; Sheehy, 2014).

Selain itu, melalui beberapa penelitian terdahulu diketahui bahwa karakteristik kepemilikan perusahaan juga dapat mempengaruhi penghindaran pajak. Perusahaan dengan kepemilikan keluarga peduli dengan reputasi perusahaan mereka dan "nama keluarga" mereka, karena mereka menganggap perusahaannya sebagai warisan untuk generasi berikutnya (Casson, 1999). Dengan demikian, kepemilikan perusahaan yang berbasis perusahaan keluarga akan mengurangi perilaku penghindaran pajak.

Aspek lain yang diklaim mempengaruhi penghindaran pajak adalah tata kelola perusahaan atau Corporate Governance (CG). CG adalah praktek mengelola organisasi dengan landasan peraturan dan etika bisnis (Tandean \& Winnie, 2016). 1) Transparansi, 2) Akuntabilitas, 3) Tanggung jawab, 4) kemandirian, dan 5) keadilan adalah lima aspek penting yang harus dipertimbangkan saat menerapkan tata kelola perusahaan yang baik untuk kesuksesan jangka panjang perusahaan. Penerapan lima poin penting tersebut dalam perusahaan dengan baik dipercaya dapat mendorongan manajemen untuk menahan diri dari tindakan penghindaran pajak (Sujendra et al., 2019).

Rujukan penelitian ini berasal dari penelitian terdahulu oleh (Sujendra et al., 2019) yang meneliti efek Corporate Social Responsibility Disclosure (CSRD), Family Ownership, dan Corporate Governance (CG) pada Penghindaran pajak. Pembeda penelitian ini dengan penelitian oleh jurnal rujukan adalah penelitian ini memanfaatkan sampel yang lebih luas tidak terbatas hanya pada perusahaan di bidang manufaktur. Selain itu, terdapat penambahan kriteria pemilihan sampel dan juga perubahan atas pengukuran variabel penelitian. Penelitian sebelumnya oleh Sujendra et al, (2019) menggunakan dummy method untuk mengukur kepemilikan keluarga dan indikator IPCG sebanyak 103 item untuk mengukur tata kelola perusahaan. Pengukuran tersebut diubah dalam penelitian ini, dimana kepemilikan keluarga diukur menggunakan total persentase kepemilikan saham oleh sebuah keluarga dan tata kelola perusahaan diukur dengan indikator CG sebanyak 15 item pengungkapan.

\section{Penelitian Terdahulu}

\section{STUDI LITERATUR}

\section{Pengaruh Pengungkapan Tanggung Jawab Sosial Perusahaan Terhadap Penghindaran Pajak}

Pengungkapan dari perusahaan terkait tanggung jawab sosial yang dilakukan perusahaan merupakan alat strategi yang dijadikan untuk membangun hubungan antara pihak stakeholder dan perusahaan. Perusahaan memiliki motivasi dalam menggunakan pengungkapan tersebut untuk mempengaruhi pandangan pihak stakeholder ke perusahaan dan tentunya juga mengalihkan pandangan atau prasangka mengenai tindakan tidak bertanggung jawab secara sosial seperti tindakan penghindaran pajak (Alsaadi, 2020). Dari penelitian terdahulu oleh Maraya dan Yendrawati (2016), Kharisma dan Faisol (2019), Gunawan (2017), Zeng (2019), Merkusiwati dan Damayanthi, (2019) serta Alsaadi (2020), variabel ini terbukti memiliki efek signifikan positif terhadap penghindaran pajak. Berdasarkan hasil penjelasan di atas, hipotesis penelitian pertama dinyatakan sebagai berikut.

$\mathrm{H}_{1}$ : Pengungkapan Tanggung Jawab Sosial Perusahaan Berpengaruh Signifikan Positif 


\section{Terhadap Penghindaran Pajak}

\section{Pengaruh Kepemilikan Keluarga Terhadap Penghindaran Pajak}

Gaaya et al. (2017), mengungkapkan bahwa perusahaan milik keluarga cenderung melakukan penghindaran pajak yang lebih agresif jika dibandingkan dengan perusahaan bukan kepemilikan keluarga. Kepemilikan keluarga ditandai dengan adanya kepemilikan saham oleh keluarga atau individu paling sedikit sebanyak dua puluh lima persen dan keluarga secara material mempengaruhi kebijakan perusahaan. Pengaruh material tersebut dapat ditentukan dengan dua cara yaitu kepemilikan saham sebesar 25\% - 50\% dan cara kedua adalah dua anggota keluarga aktif dalam manajemen (Kovermann dan Wendt, 2019). Hubungan positif terjadi ketika penambahan kepemilikan keluarga akan menyebabkan peningkatan tindakan penghindaran pajak. Hasil penelitian lain yang menunjukkan hubungan positif kepemilikan keluarga dengan penghindaran pajak adalah adalah Kovermann dan Wendt (2019), Saputra, Susanti, Istiarto (2019) dan Ayunanta, Mawardi, dan Malikah (2020). Berdasarkan hasil penjelasan di atas, hipotesis penelitian kedua dinyatakan sebagai berikut.

\section{Pajak}

$\mathrm{H}_{2}$ : Kepemilikan Keluarga Berpengaruh Signifikan Positif Terhadap Penghindaran

\section{Pengaruh Tata Kelola Perusahaan Terhadap Penghindaran Pajak}

Pada penelitian terhadulu oleh Darmawan dan Sukartha (2014), dijelaskan apabila tata kelola perusahaan diimplementasikan dengan baik maka akan menjadi penekan wajib pajak perusahaan untuk tidak melakukan penghindaran pajak. Kusbandiyah et al. (2021) juga menjelaskan bahwa dari implementasi dari tata kelola perusahaan yang baik mengefisiensikan kinerja perusahaan serta dapat dijadikan sebagai alat mencegah perusahaan dalam melakukan penghindaran pajak oleh pemerintah terhadap perusahaan. Disimpulkan dari hasil uji bahwa tata kelola perusahaan memiliki hubungan negatif terhadap penghindaran pajak. Hasil penelitian Darmawan dan Sukartha (2014) dan Kusbandiyah et al. (2021) tersebut searah dengan penelitian yang dilakukan oleh Salhi et al. (2019), dan Handayani dan Ibrani (2019). Berdasarkan hasil penjelasan di atas, dirumuskan hipotesis penelitian sebagai berikut. Pajak

$\mathrm{H}_{3}$ : Tata Kelola Perusahaan Berpengaruh Signifikan Negatif Terhadap Penghindaran

\section{METODE}

Penelitian untuk pengembangan teori yang sudah ada ini memanfaatkan pendekatan kuantitatif, dimana data observasi dalam penelitian berbentuk bilangan atau angka. Data dan informasi yang diperlukan dalam penelitian didapatkan melalui laporan tahunan, laporan keuangan, dan laporan keberlanjutan perusahaan mulai dari periode 2016-2020. Data-data yang dibutuhkan tersebut dapat diperoleh melalui situs resmi perusahaan terkait dan situs resmi seperti http://www.idx.com (Indonesian Stock Exchange). Parameter pemilihan sampel penelitian ini adalah: (1) Perusahaan telah terdaftar dalam Bursa Efek Indonesia (BEI) dan bukan merupakan perusahaan keuangan (2) Perusahaan yang menjadi sampel penelitian telah menerbitkan laporan tahunan selama lima periode yakni mulai dari 2016 hingga tahun 2020 (3) Perusahaan yang masih beroperasi selama pelaksanaan penelitian (4) Perusahaan tidak mengalami rugi selama periode pelaksanaan penelitian dan memiliki rasio ETR di atas 1.

Tabel 1. Sampel dan Data Penelitian

\begin{tabular}{|l|c|}
\hline \multicolumn{1}{|c|}{ Keterangan } & Jumlah \\
\hline Perusahaan dalam BEI 2016-2020 & 728 \\
\hline Perusahaan IPO setelah 2016 & $(208)$ \\
\hline $\begin{array}{l}\text { Perusahaan yang berhenti menerbitkan laporan tahunan } \\
\text { selama periode penelitian }\end{array}$ & $(35)$ \\
$\begin{array}{l}\text { Perusahaan keuangan } \\
\text { Perusahaan yang mengalami kerugian dan/atau tidak } \\
\text { memiliki beban pajak dan ETR di atas 1 } \\
\text { Perusahaan sampel penelitian }\end{array}$ & $(88)$ \\
\hline
\end{tabular}


Owner: Riset \& Jurnal Akuntansi

e-ISSN : 2548-9224 | p-ISSN : 2548-7507

Volume 6 Nomor 1, Januari 2022

DOI : https://doi.org/10.33395/owner.v6i1.599

\begin{tabular}{|l|c|}
\hline Total data sampel & 680 \\
\hline Total data outlier & $(89)$ \\
\hline Total data sampel setelah dikurangi outlier & 591 \\
\hline
\end{tabular}

Sumber: data sekunder diolah (2021)

\section{Definisi Operasional Variabel \\ Penghindaran Pajak}

Penghindaran pajak diproksikan dengan Effective Tax Rate (ETR) untuk membuktikan korelasi antar variabel. ETR memiliki kisaran nilai mulai dari diatas 0 dan kurang dari 1 (Astuti \& Aryani, 2016). Nilai ETR dapat diperoleh menggunakan rumus sebagai berikut (Maharani \& Juliarto, 2019):

$$
E T R=\frac{\text { Total tax expense }}{\text { Pre }- \text { tax income }}
$$

\section{Pengungkapan Tanggung Jawab Sosial Perusahaan}

Variabel independen pertama dalam penelitian ini menggunakan indikator dari GRI Standards, dimana total indikator pengungkapan adalah sebanyak 91 item dan jika item indikator tersebut diungkapkan dalam laporan keberlanjutan maka akan diberi poin 1 dan 0 jika tidak diungkapkan. Total dari indikator yang diungkapkan akan dibagikan dengan jumlah seluruh indikator yaitu 91 item. Berikut rumus yang digambarkan melalui penjelasan di atas:

$$
\mathrm{CSRIj}=\frac{\sum X y i}{n i}
$$

\section{Kepemilikan Keluarga}

Penelitian oleh Kovermann dan Wendt (2019), kepemilikan keluarga diukur dengan membandingkan jumlah saham yang dipunyai pihak keluarga dan total saham perusahaannya yang beredar di bursa. Rumus dapat digambarkan sebagai berikut:

$$
K K=\frac{\text { Shares owned by family }}{\text { Shares oustanding }}
$$

Kepemilikan keluarga ditandai dengan adanya kepemilikan saham oleh keluarga atau individu paling sedikit sebanyak dua puluh lima persen dan keluarga secara material mempengaruhi kebijakan perusahaan. Pengaruh material tersebut dapat ditentukan dengan dua cara yaitu kepemilikan saham sebesar 25\% 50\% dan cara kedua adalah dua anggota keluarga aktif dalam manajemen.

\section{Tata Kelola Perusahaan}

Tata kelola perusahaan diukur dengan 15 item indikator dari Indonesia CG Index (ICGI) oleh Tanjung (2020). 15 indikator tersebut terdiri dari (1) Code of ethics, (2) Anti-corruption, (3) Insider trading, (4) Largest shareholder, (5) Free float (Public share ownership), (6) Employees share ownerships, (7) CSR, (8) Whistleblowing, (9) Sanctions, (10) Big4 auditors, (11) Disclosure of the ultimate beneficiary shareholders, (12) Independent director, (13) Independent commissioner, (14) Size of the board of director, (15) Size of the board of commissioner. Satu poin diberikan setiap pemenuhan satu indikator. Total poin indikator yang dipenuhi akan dibagi dengan total jumlah indikator yang ada yaitu 15 indikator. Berikut rumus yang digambarkan melalui penjelasan di atas:

\section{Model Regresi Penelitian}

$$
\mathrm{ICGI}=\frac{\sum X y i}{n i}
$$


Penelitian ini merupakan penelitian menggunakan teknik analisis data panel. Regresi data panel penelitian ini memanfaatkan SPSS dan Eviews sebagai pengelola data. SPSS akan digunakan untuk melampirkan deskriptif statistik dan mendeteksi outlier dalam data observasi yang mungkin akan menyebabkan distorsi pada hasil uji. Outlier yang terdeteksi harus dikeluarkan sebelum melanjutkan pengujian hasil penelitian menggunakan Eviews. Luaran yang akan diperoleh dari Eviews adalah sebanyak tiga model regresi. Model regresi yang akan digunakan untuk membuktikan korelasi antar variabel hanya satu dan akan dipilih dengan cara melakukan uji kesesuaian model yakni uji chow dan hausman test. Model yang layak dan terpilih melalui uji kesesuaian model akan digunakan untuk interpretasimi pembuktian hasil penelitian.

\section{Statistik Deskriptif}

HASIL

Tabel 2. Luaran Statistik Deskriptif

\begin{tabular}{|c|c|c|c|c|c|}
\hline Variabel & $\boldsymbol{N}$ & Minimum & Maximum & Mean & Std. Deviation \\
\hline ETR & 680 & 0,0005 & 0,9621 & 0,2417 & 0,1383 \\
\hline CSRD & 680 & 0,0000 & 0,7143 & 0,0605 & 0,1399 \\
\hline KK & 680 & 0,0000 & 0.9324 & 0.3498 & 0.3408 \\
\hline CG & 680 & 0,2000 & 0,9333 & 0,6650 & 0,1392 \\
\hline
\end{tabular}

Sumber: Pengelolahan data SPSS (2021)

Dilihat dari apa yang terlampir dalam tabel di atas, jumlah data yang memenuhi syarat sebagai sampel adalah sebanyak 680 data observasi dan variabel pertama yaitu penghindaran pajak memiliki rasio paling kecil yakni 0,0005 menandakan tingginya upaya salah satu perusahaan sampel dalam melakukan penghindaran pajak sedangkan paling besar yakni 0,9621 menandakan salah satu sampel penelitian taat dan tidak melakukan penghindaran pajak. Nilai minimum dan maksimum tersebut diikuti nilai mean 0,2417 yang berarti rata-rata rasio penghindaran pajak perusahaan sampel sebesar 24,17\%. Selain itu, nilai standar deviasi menunjukkan nilai 0,1383 menandakan besarnya variasi dari data yakni sebesar $13,83 \%$.

Untuk variabel kedua yaitu pengungkapan tanggung jawab sosial perusahaan, nilai minimum 0 berasal dari berbagai perusahaan yang tidak mengungkapkan laporan keberlanjutan perusahaan dan menunjukkan bahwa partisipasi pengungkapan laporan keberlanjutan dari perusahaan masih sangat rendah. Nilai maksimum adalah 0,7143 berasal dari PT Bukit Asam Tbk (2020). Nilai maksimum tersebut menjelaskan bahwa kelengkapan pengungkapan tanggung jawab perusahaan PT Bukit Asam Tbk tergolong lengkap dan paling lengkap jika di bandingkan dengan perusahaan lainnya. Rata-rata atau mean dari variabel ini adalah 0,0605 , dimana nilai ini dapat dikatakan cukup rendah dikarenakan banyaknya perusahaan yang tidak menerbitkan laporan keberlanjutan. Nilai dari standar deviasi variabel ini adalah 0,1399 yang berarti data memiliki variasi data sebesar $13,99 \%$.

Untuk variabel ketiga yaitu kepemilikan keluarga atau variabel terakhir dalam penelitian ini, nilai minumun perusahaan berada di $0 \%$ disebabkan oleh tidak adanya kepemilikan saham keluarga dibeberapa perusahaan dan nilai maksimum sebesar 0,9325 atau 93,25\% berasal dari PT Multifiling Mitra Indonesia Tbk (2017). Kepemilikan perusahaan tersebut dimiliki secara langsung tidak langsung oleh keluarga Riady melalui perusahaan lain miliknya. Pada variabel kepemilikan keluarga ini, nilai rata-rata kepemilikan saham berada pada 34,98\% dan memiliki tingkat data yang lebih bervariasi dibandingkan dengan variabel lainnya yakni sebesar $34,08 \%$. Hal tersebut disebabkan oleh banyaknya perusahaan sampel yang tidak mempunyai kepemilikan keluarga dan beragamnya persentase kepemilikan keluarga mulai dari 25\% sampai dengan $93,25 \%$.

Selanjutnya variabel independen keempat yaitu tata kelola perusahaan, nilai minimum sebesar 0,2000 berasal dari PT J Resources Asia Pasifik Tbk (2020) yang menunjukkan rendahkan tata kelola perusahaan. Nilai minimum tersebut diikuti dengan nilai maksimum sebesar 0,9333 yang berasal dari Mitra Pinasthinka Mustika Tbk (2016). Selanjutnya nilai rata-rata tata kelola perusahaan adalah 0,6650 disebabkan oleh nilai implementasi tata kelola setiap sampel perusahaan yang cukup tinggi. Variabel tata kelola perusahaan kemudian memiliki standar 
Owner: Riset \& Jurnal Akuntansi

e-ISSN : 2548-9224 | p-ISSN : 2548-7507

Volume 6 Nomor 1, Januari 2022

DOI : https://doi.org/10.33395/owner.v6i1.599

deviasi 0,1392 yang mempunyai arti tingkat variasi dari data observasi hanya sebesar 13,92\%.

\section{Outlier}

Sebelum menjalankan uji regresi berganda, uji outlier harus dilakukan guna mendeteksi dan membuang data yang mungkin akan membuat hasil uji menjadi tidak bagus. Data dideteksi sebagai data outlier apabila mempunyai nilai SDR > 1,96 atau <-1,96. Dalam mendeteksi outlier menggunakan SPSS ditemukan 89 data outlier yang perlu dibuang sebelum melanjutkan uji menggunakan program Eviews 10.

\section{Pemilihan Model Regresi Uji Chow}

Tabel 3. Luaran Uji Chow

\begin{tabular}{|l|c|c|c|}
\hline Effect Test & Statistic & d.f. & Prob. \\
\hline Cross-section F & 6,986843 & $(132,455)$ & 0,0000 \\
\hline Cross-section Chi-square & 654,565767 & 132 & 0,0000 \\
\hline
\end{tabular}

Sumber: Pengolahan data Eviews (2021)

Terlampirnya Cross-section chi square dengan nilai $0,0000 \leq 0,05$ di atas, menyiratkan model regresi yang paling layak untuk membuktikan korelasi variabel penelitian adalah model Fixed Effect Model (FEM).

\section{Hausman test}

Tabel 4. Luaran Hausman Test

\begin{tabular}{|l|l|l|l|}
\hline Test Summary & Chi-Sq. Statistic & Chi-Sq. d.f & Prob. \\
\hline Cross-section random & 3,859384 & 3 & 0,2771 \\
\hline
\end{tabular}

Sumber: Pengolahan data Eviews (2021)

Nilai Cross-section random di atas terlampir sebesar $0,2771 \geq 0,05$ menyiratkan bahwa model regresi Random Effect Model (REM) lebih layak digunakan untuk membuktikan korelasi antar variabel dalam penelitian ini dibandingkan dengan model regresi Fixed Effect Model (FEM).

\section{Luaran Uji Hipotesis}

Uji F

Tabel 5. Luaran Uji F

\begin{tabular}{|c|c|c|}
\hline Variabel Dependen & Sig. & Kesimpulan \\
\hline ETR & 0,002435 & Signifikan \\
\hline
\end{tabular}

Sumber: Luaran Random Effect Model Eviews (2021)

Nilai signifikansi tes $\mathrm{F}$ adalah $0,002435 \leq 0,05$ yang terlampir pada tabel 5 di atas menyiratkan ketiga variabel independen penelitian memiliki efek simultan pada variabel dependen. Artinya, terdapat dampak simultan dari pengungkapan tanggung jawab sosial perusahaan, kepemilikan keluarga, dan tata kelola perusahaan pada penghindaran pajak.

\section{Uji t}

Tabel 6. Luaran Uji t

\begin{tabular}{|c|c|c|c|c|c|}
\hline Variabel & Coefficient & Std. Error & t-Statistic & Prob. & Hipotesis \\
\hline C & 0,2261 & 0,0222 & 10,1447 & 0,0000 & \\
\hline CSRD & $-0,0839$ & 0,0244 & $-3,4387$ & 0,0006 & $\mathrm{H}_{1}$ Terbukti \\
\hline KK & $-0,0330$ & 0,0159 & $-2,0669$ & 0,0392 & $\mathrm{H}_{2}$ Terbukti \\
\hline CG & 0,0330 & 0,0308 & 0,9721 & 0,3314 & $\mathrm{H}_{3}$ Tidak terbukti \\
\hline
\end{tabular}

Sumber: Luaran Random Effect Model Eviews (2021) 
Ditunjukan hasil uji di atas, hasil negatif pada hasil uji menyatakan pengaruh arah positif sedangkan hasil uji positif menandakan pengaruh arah negatif. Keterbalikan tersebut disebabkan oleh penggunaan ETR sebagai pengukuran dari penghindaran pajak. Pada pengukuran ETR, semakin kecil nilai rasio ETR menandakan upaya penghindaran yang semakin tinggi dan juga sebaliknya. Jadi apabila pada tabel coefficient menunjukkan hasil negatif, hal itu menandakan jika terjadi kenaikan satu satuan pada variabel independen, maka nilai ETR akan menurun sesuai dengan nilai kenaikan variabel independen tersebut. Nilai ETR yang menurun tersebutlah yang menandakan penghindaran pajak semakin tinggi. Disimpulkan kenaikan variabel independen tersebut diikuti dengan kenaikan penghindaran pajak dan ini menjelaskan bahwa adanya hubungan positif antar variabel. Oleh karena penjelasan tersebut, keterbalikan dalam tata cara pembacaan hasil uji ini terjadi.

Berdasarkan hasil uji Hipotesis (1) di atas, dijelaskan bahwa setiap terjadi peningkatan sebuah satuan atas keterbukaan pengungkapan tanggung jawab sosial oleh perusahaan akan menurunkan nilai ETR sebesar 0,0839. Nilai ETR yang menurun menandakan tingginya upaya penghindaran pajak perusahaan sampel atau menunjukkan korelasi positif terhadap variabel dependen.

Luaran Uji Hipotesis (2) menjelaskan setiap kenaikan 1\% kepemilikan saham oleh keluarga, nilai ETR akan ikut menurun sebesar 0,0330. Penurunan nilai ETR tersebut menandakan semakin tingginya upaya penghindaran pajak yang dilakukan oleh perusahaan atau menunjukkan korelasi positif terhadap variabel dependen.

Uji Hipotesis (3) menunjukkan probabilitas sebesar $0,3314 \geq 0.05$ nilai alpha. Nilai tersebut menandakan bahwa variabel ketiga dalam penelitian ini tidak memiliki pengaruh yang signifikan terhadap penghindaran pajak. Nilai koefisien dari variabel tersebut adalah 0,0330 yang berarti setiap peningkatan satu satuan implementasi tata kelola perusahaan, maka nilai ETR akan naik dan kenaikan tersebut menandakan penurunan upaya penghindaran pajak. Singkatnya, dapat dikatakan bahwa tata kelola perusahaan dapat menekan penurunan upaya penghindaran pajak dari perusahaan-perusahaan yang ada tetapi tidak secara signifikan mempengaruhinya.

\section{Hasil Uji Goodness of Fit Model}

Tabel 7. Luaran Uji Goodness of Fit Model

\begin{tabular}{|c|c|c|}
\hline Variabel Dependen & R Square & Adjusted R Square \\
\hline ETR & 0,024174 & 0,019187 \\
\hline
\end{tabular}

Sumber: Luaran Random Effect Model Eviews (2021)

Terlampir pada tabel di atas nilai 0.019187 pada kolom Adjusted $R$ Square menyiratkan bahwa variabel independen yang dipakai dalam penelitian ini terbukti dapat menerangkan variabel dependen sebesar $1,9187 \%$. Sisanya $98.0813 \%$ dijelaskan variabel bebas lainnya yang tidak diikut sertakan dalam penelitian ini.

\section{PEMBAHASAN}

\section{Pengaruh Pengungkapan Tanggung Jawab Sosial Perusahaan Terhadap Penghindaran Pajak}

Dalam penelitian terdahulu oleh Hidayati dan Fidiana (2017), dijelaskan beberapa item indikator dalam pengungkapan tanggung jawab sosial perusahaan adalah pengeluaran yang dapat dibebankan untuk mengurangi penghasilan kena pajak perusahaan. Selain itu, pengungkapan yang dilakukan perusahaan dapat dijadikan sebagai pengalihan perhatian agar perusahaan dapat menaikan citra nama baik perusahaan dan mengurangi beban pajak yang perlu dibayarkan kepada negara (Gunawan, 2017).

Hasil penelitian ini bertolakan dengan penelitian terdahulu oleh Sujendra et al. (2019) tetapi didukung oleh penelitian terdahulu yang berasal dari Maraya dan Yendrawati (2016), Hidayati dan Fidiana (2017), Gunawan (2017), Kharisma dan Faisol (2019), Zeng (2019), Merkusiwati dan Damayanthi, (2019) dan Alsaadi, (2020). Hipotesis (1) penelitian menyatakan pengungkapan tanggung jawab sosial perusahaan berpengaruh signifikan dan positif terhadap penghindaran pajak terbukti dan diterima.

\section{Pengaruh Kepemilikan Keluarga Terhadap Penghindaran Pajak}


Hasil penelitian ini bertolakan dengan penelitian terdahulu oleh Sujendra et al. (2019) yang menyatakan bahwa kepemilikan keluarga tidak mempengaruhi upaya penghindaran pajak. perbedaan tersebut dapat disebabkan oleh perbedaan metode pengukuran atau bedanya sampel penelitian yang digunakan. Hasil penelitian ini didukung oleh penelitian terdahulu dari Gaaya et al. (2017), Kovermann dan Wendt (2019), Saputra, Susanti, Istiarto (2019) dan Ayunanta, Mawardi, dan Malikah (2020).

Ayunanta, Mawardi, dan Malikah (2020) menjelaskan bahwa sistem pemungutan pajak selfassessment dan ringannya sanksi saat terbukti melakukan penghindaran pajak mendorong wajib pajak untuk melakukan tindakan tersebut. Hipotesis (2) menyatakan kepemilikan keluarga memiliki pengaruh signifikan dan positif terhadap penghindaran pajak terbukti dan diterima.

\section{Pengaruh Tata Kelola Perusahaan Terhadap Penghindaran Pajak}

Bukti korelasi tata kelola perusahaan terhadap penghindaran pajak pada penelitian ini bertolakan dengan penelitian terdahulu oleh Sujendra et al. (2019). Pada penelitiannya, tata kelola perusahaan dikatakan efektif dalam menurunkan angka penghindaran pajak perusahaan yang berarti adanya korelasi negatif antar variabel. Tidak sama dengan penelitian ini yang menunjukkan bahwa tata kelola perusahaan tidak berpengaruh terhadap penghindaran pajak. Pendukung atas penelitian ini datang dari Gunawan (2017) dan Kusbandiyah et al. (2020).

Gunawan (2017) menjelaskan pemerintah sendiri menyediakan aturan-aturan mengenai tata kelola perusahaan yang wajib dipenuhi oleh perusahaan terbuka, sehingga keterbukaan ataupun tata kelola yang baik dari perusahaan dilakukan hanya sekedar untuk pemenuhan kewajiban dari peraturan pemerintah. Oleh karena itu, dapat dikatakan bahwa ketaatan atas implementasi tata kelola perusahaan hanyalah sebagai cerminan keikutsertaan atas aturan yang ada dan tidak benarbenar secara signifikan mempengaruhi angka penghindaran pajak dalam perusahaan. Hipotesis (3) yang memiliki asumsi tata kelola perusahaan memiliki korelasi signifikan negatif terhadap penghindaran pajak tidak terbukti dan ditolak.

\section{KESIMPULAN}

Tujuan utama pelaksanaan penelitian ialah membuktikan efek dari tiga buah variabel independen yang digunakan dalam penelitian ini pada upaya penghindaran pajak perusahaan $G o$ public yang ada di Indonesia. Hasil uji dan pembahasan di atas telah membuktikan pengungkapan tanggung jawab sosial perusahaan $\left(\mathrm{X}_{1}\right)$ serta kepemilikan keluarga $\left(\mathrm{X}_{2}\right)$ mempunyai korelasi positif dan secara signifikan mempengaruhi tingginya upaya penghindaran pajak oleh perusahaan. korelasi positif menandakan semakin luasnya pengungkapan atas tanggung jawab sosial yang dilakukan perusahaan dan semakin besar porsi persentase kepemilikan keluarga akan menyebabkan upaya penghindaran pajak yang semakin tinggi. Sedangkan variabel terakhir atau tata kelola perusahaan $\left(\mathrm{X}_{3}\right)$ tidak mempengaruhi penghindaran pajak. Pembahasan penelitian atas korelasi antar variabel telah didukung oleh beragam penelitian terdahulu lainnya. Perbedaan korelasi antar variabel penelitian ini dengan penelitian rujukan sebelumnya mungkin disebabkan oleh ketidaksamaan atas pengukuran, tahun penelitian, dan luas sampel penelitian yang digunakan.

\section{REFERENSI}

Alsaadi, A. (2020). Financial-tax reporting conformity, tax avoidance and corporate social responsibility. Journal of Financial Reporting and Accounting, 18(3), 639-659. https://doi.org/10.1108/JFRA-10-2019-0133

Amila Dyan Maraya, R. Y. (2016). Pengaruh corporate governance dan corporate social responsibility disclosure terhadap tax avoidance: studi empiris pada perusahaan tambang dan CPO. Jurnal Akuntansi \& Auditing, 20(2).

Ani Kusbandiyah, Norlia Mat Norwani, M. A. J. (2021). Determinants of Tax Avoidance of Public Listed Companies in Indonesia. Turkish Journal of Computer and Mathematics Education (TURCOMAT), 12(3), 592-601. https://doi.org/10.17762/turcomat.v12i3.764

Ayunanta, L. Y., Mawardi, M. C., \& Malikah, A. (2020). Pengaruh Profitabilitas, Kepemilikan 
Keluarga, Corporate Governance Dan Kepemilikan Institusional Terhadap Penghindaran Pajak Di Indonesia (Studi Empiris Pada Perusahaan Food and Beverage Yang Terdaftar di Bursa Efek Indonesia Periode 2015-2018). E-Jra, 09(12), 30-45.

Casson, M. (1999). The economics of the family firm. Scandinavian Economic History Review, 47(1), 10-23. https://doi.org/10.1080/03585522.1999.10419802

Darmawan, I., \& Sukartha, I. (2014). Pengaruh Penerapan Corporate Governance, Leverage, Roa, Dan Ukuran Perusahaan Pada Penghindaran Pajak. E-Jurnal Akuntansi, 9(1), 143-161.

Dewi, Ni Nyoman Kristiana; Jati, I. K. (2014). Pengaruh karakter eksekutif, karakteristik perusahaan, dan dimensi tata kelola perusahaan yang baik pada tax avoidance di bursa efek indonesia. 2, 249-260.

Gaaya, S., Lakhal, N., \& Lakhal, F. (2017). Does family ownership reduce corporate tax avoidance? The moderating effect of audit quality. Managerial Auditing Journal, 32(7), 731-744. https://doi.org/10.1108/MAJ-02-2017-1530

Gunawan, J. (2017). Pengaruh Corporate Social Responsibility Dan Corporate Governance Terhadap Agresivitas Pajak. Jurnal Akuntansi, 21(3), 425-436. https://doi.org/10.24912/ja.v21i3.246

Handayani, Y. D., \& Ibrani, E. Y. (2019). Corporate Governance , Share Ownership Structure And Tax Avoidance. International Journal of Commerce and Finance, 5(2), 120-127.

Hidayati, N., \& Fidiana. (2017). Pengaruh Corporate Governance Social Responsibility dan Good Corporate Governance terhadap Pengindaran Pajak. Jurnal Ilmu Dan Riset Akuntansi, 6(3), 1053-1070.

Kharisma, M., \& Faisol, D. A. (2019). Effect of Corporate Social Responsibility and Company Transparency on Tax Avoidance with Profitability as Moderating Variables ( In Manufacturing Companies That Are Listing on The Idx 2015 - 2017 Period ). Economics and Finance, 9771, 439-443. https://doi.org/10.21276/sb.2019.5.8.5

Kovermann, J., \& Wendt, M. (2019). Tax avoidance in family firms: Evidence from large private firms. Journal of Contemporary Accounting and Economics, 15(2), 145-157. https://doi.org/10.1016/j.jcae.2019.04.003

Kusbandiyah, A., Mat Norwani, N., \& Jusoh, M. A. (2020). Aggressive Tax Avoidance Determinant Factors of $\mathrm{Cg}$ Rankings 100 Public Companies by Indonesian Institute for Corporate Directorship. Advances in Business Research International Journal, 6(1), 35. https://doi.org/10.24191/abrij.v6i1.9938

Maharani, W., \& Juliarto, A. (2019). Pengaruh Kepemilikan Keluarga Terhadap Tax Avoidance Dengan Kualitas Audit Sebagai Variabel Moderating. Diponegoro Journal of Accounting, $8(4), 1-10$.

Merkusiwati, N. K. L. A., \& Eka Damayanthi, I. G. A. (2019). Pengaruh Pengungkapan CSR, Karakter Eksekutif, Profitabilitas, Dan Investasi Aktiva Tetap Terhadap Penghindaran Pajak. E-Jurnal Akuntansi, 29(2), 833. https://doi.org/10.24843/eja.2019.v29.i02.p26

Michael C. JENSEN, W. H. M. (1976). THEORY OF THE FIRM: MANAGERIAL BEHAVIOR, AGENCY COSTS AND OWNERSHIP STRUCTURE. Journal of Financial Economics, 72(10), 305-360. https://doi.org/10.1177/0018726718812602

Puji, T., \& Aryani, Y. A. (2016). TREN PENGHINDARAN PAJAK PERUSAHAAN MANUFAKTUR DI INDONESIA YANG TERDAFTAR DI BEI TAHUN 2001-2014. XX(03), 375-388.

Ratmono, D., \& Sagala, W. M. (2016). PENGUNGKAPAN CORPORATE SOCIAL RESPONSIBILITY (CSR) SEBAGAI SARANA LEGITIMASI: DAMPAKNYA TERHADAP TINGKAT AGRESIVITAS PAJAK. Nominal, Barometer Riset Akuntansi Dan Manajemen. https://doi.org/10.21831/nominal.v4i2.7997

Salhi, B., Riguen, R., Kachouri, M., \& Jarboui, A. (2019). The mediating role of corporate social responsibility on the relationship between governance and tax avoidance: UK common law versus French civil law. Social Responsibility Journal. https://doi.org/10.1108/SRJ-042019-0125

Saputra, M. D., Susanti, J., \& Istiarto. (2019). PENGARUH PROFITABILITAS, KEPEMILIKAN KELUARGA DAN CORPORATE GOVERNANCE TERHADAP 
PENGHINDARAN PAJAK DI INDONESIA. VALID Jurnal Ilmiah, 16(2), 164-179.

Sujendra, i M., Ratnadi, N. M. D., Sari, M. M. R., \& Rasmini, N. ketut. (2019). The Effect of Corporate Social Responsibility Disclosure, Family Ownership, and Good Corporate Governance in Tax Avoidance. Research Journal of Finance and Accounting, 10(6), 44-49. https://doi.org/10.7176/RJFA

Tandean, V. A., \& Winnie. (2016). The Effect of Good Corporate Governance on Tax Avoidance. Asian Journal of Accounting Research, 1(1), 28-38. https://doi.org/10.1108/AJAR-2016-0101-B004

Tanjung, M. (2020). A cross-firm analysis of corporate governance compliance and performance in Indonesia. Managerial Auditing Journal, 35(5), 621-643. https://doi.org/10.1108/MAJ06-2019-2328

Zeng, T. (2019). Relationship between corporate social responsibility and tax avoidance: international evidence. Social Responsibility Journal, 15(2), 244-257. https://doi.org/10.1108/SRJ-03-2018-0056 